Review Article

\title{
Conceptual Analysis of Nasya Karma in Netra Rogas
}

\author{
Swathi $\mathrm{AC}^{1}$, Naveen $\mathrm{BS}^{2}$, Ajoy Viswam ${ }^{3}$, Krishnan Namboodiri ${ }^{4}$ \\ ${ }^{1}$ P.G. Scholar, ${ }^{2}$ Professor \& HOD, ${ }^{3,4}$ Assistant Professor, Department of Shalakya Tantra, Sri Sri College of Ayurvedic Science \& \\ Research Hospital, Bangalore, Karnataka, India.
}

DOI: https://doi.org/10.24321/2394.6547.202008

\section{I $\quad \mathbf{N} \quad \mathbf{F} \quad \mathbf{O}$}

\section{Corresponding Author:}

Swathi AC, Department of Shalakya Tantra, Sri Sri College of Ayurvedic Science \& Research Hospital, Bangalore, Karnataka, India.

E-mail Id:

drswathiac@gmail.com

Orcid Id:

https://orcid.org/0000-0003-0179-9208

How to cite this article:

Swathi AC, Naveen BS, Viswam A, Namboodiri K. Conceptual Analysis of Nasya Karma in Netra Rogas. J Adv Res Ayur Yoga Unani Sidd Homeo 2020; 7(3\&4): 11-15.

Date of Submission: 2020-12-o9

Date of Acceptance: 2020-12-22

\section{$\begin{array}{lllllllllll}\mathbf{A} & \mathbf{B} & \mathbf{S} & \mathbf{T} & \mathbf{R} & \mathbf{A} & \mathbf{C} & \mathbf{T}\end{array}$}

Panchakarma plays an important role in Ayurveda, which does the function of cleansing the body from Doshas. Among them, Nasya is mainly indicated for Urdhwajatrugata Vikaras, in which Doshas are eliminated by means of the nearest possible opening, the nose. Netra, being considered as the important Indriya among others, should be protected with utmost care. Considering Ama-Nirama concept of Netra, treatment of Netra Roga is decided in which Sthanika Dosha Shodhana is very essential. For that, Nasya Karma is considered as an option among other Shodhana Karmas. A proper Shodhana at proper stage of a disease can avoid unnecessary surgeries even. Benefits of Nasya Karma in Netra Rogas are already proved through various previous studies.

This article is an attempt to conceptually analyze the role of Nasya Karma in Netra Rogas through various literature sources of Ayurveda and contemporary science.

Keywords: Netra Rogas, Nasya Karma, Shodhana Karma

\section{Introduction}

Netra, the most important Indriya among all others has to be treated with all the efforts. Acharya Sushruta has differentiated the Netra Rogas into Aushadha Sadhya Vyadhis, Shastra Sadhya Vyadhis and Asadhya Vyadhis on the basis of Sadhyasadhyata. In the case of Aushadha Sadhya Vyadhis, Nasya plays a very important role. Especially while doing Kriyakalpas. Aushadha Sadhya Vyadhis have to be treated on the basis of Ama-Nirama Lakshana of Netra. Few treatments like Seka, Aschyotana can be done in any stage of the Netra Rogas. Yet proper removal of Ama Lakshana of Netra is necessary before Netra Roga Chikitsa in order to remove Srotavarodha followed by a proper Shodhana. Further treatments can be given after the Shodhana which would promote effective results.

Nasya, which is a Shodhana Karma, can be considered in this context. Nasya is the prime treatment modality for Urdhwajatru Vikaras. Nasa is said to be the route to Shiras. ${ }^{1}$ Medicines administered through Nasa, spread above the clavicle region and get absorbed to get rid of disease. The root word of the term Nasya is "Nasa" which conveys the pathway ie, "Gati". ${ }^{2}$ Here, Gati is towards the internal structures like Netra, Shirah, Kantha, Mukha.

Due to the modern life style, diseases of eyes are so common. So, implementing Nasya Karma along with Kriyakalpas can give promising results for Netra Rogas.

\section{Ayurvedic Review}

Nasya refers to the instillation of Aushadhas processed in Sneha into nostrils. ${ }^{3}$ According to Kaala, time of administration is differentiated. Nasya is given in Pratah (morning) for Kaphaja Vikaras, Madhyahna (mid noon) for Pittaja Vikaras and Sayahna (evening) and Nisha (night) 
for Vataja Vikaras. In Sharat and Vasanta Ritu, it is given in Poorvahna (morning) for Swastha. In Shita Ritus like Hemanta and Shishira it should be given in Madhyahna (mid noon), in Grishma Ritu, in Sayahna (evening), and in Varsha Ritu when there is presence of sun. ${ }^{4}$

Importance of Nasya can be seen in various another contexts also. For example, in case of Tarpana, Nasya should be given to the patient as Purva Karma ${ }^{5}$ and Kayashudhi should be done prior to Anjana ${ }^{6}$ according to Acharya Sushruta. Acharya Dalhana has given explanation for this by describing Nasya as one among the Shodhana Karmas for achieving Kayashudhi. ${ }^{6}$

Nasya Karma is of various types according to different Acharyas (Table 1).

Nasya can be considered in two aspects.

Table I.Types of Nasya Karma according to different Acharyas

\begin{tabular}{|c|c|c|}
\hline S. No. & Acharyas & Types \\
\hline 1. & Sushruta $^{3}$ & $\begin{array}{r}\text { Nasyam, Shirovirechana, } \\
\text { Pratimarsha, Avapeedaka, } \\
\text { Pradhamana }\end{array}$ \\
\hline 2. & Vagbhata $^{7}$ & $\begin{array}{r}\text { Virechana, Brimhana, } \\
\text { Shamana }\end{array}$ \\
\hline 3. & Charaka $^{8}$ & $\begin{array}{r}\text { Rechana, Tarpana, } \\
\text { Shamana }\end{array}$ \\
\hline
\end{tabular}

\section{Preventive Aspect}

Nasya is even incorporated as a part of Dinacharya by Acharyas owing to its significance. Pratimarsha Nasya can be considered as preventive aspect in order to delay ageing process and thereby maintaining the Netra Swasthyam. This type of Nasya is the one which can be given on daily basis in less quantity of medicines.

\section{Curative Aspect}

Nasya Karma can be seen as one of the important treatment protocols for various Netra Rogas. For curing some particular disease, Nasya can be given as Shamana in the form of Pratimarsha Nasya and as Shodhana in the form of Marsha Nasya.

In classics, various formulations for Nasya are specifically indicated for different Netra Rogas (Tables 2 and 3).

\section{Materials and Methods}

All the relevant Ayurvedic classical text books like Ashtanga Hridaya, Sushruta Samhita, Charaka Samhita and various research articles, scientific websites and contemporary science books of the concerned subjects were referred and critically analysed.
Table 2.Various types of Nasya formulations indicated for different Netra Rogas by Acharya Sushruta

\begin{tabular}{|c|c|}
\hline Disease & Drugs for Nasya \\
\hline Vataja Abhishyanda ${ }^{9}$ & $\begin{array}{c}\text { Sthiraksheeramadhura } \\
\text { Taila }\end{array}$ \\
\hline Pittaja Abhishyanda ${ }^{10}$ & Ksheera/Sarpi Nasya \\
\hline $\begin{array}{c}\text { Shleshmaja Abhishyanda, } \\
\text { Balasagrathita, Pishtaka, } \\
\text { Praklinna Vartma, Kaphaja } \\
\text { Akshiroga }{ }^{11}\end{array}$ & $\begin{array}{c}\text { Navana with } \\
\text { Shringavera, Suradaaru, } \\
\text { Musta }\end{array}$ \\
\hline Raktaja Abhishyanda ${ }^{12}$ & $\begin{array}{l}\text { Vairechanika dravya + } \\
\text { Sita+ Sarpi }\end{array}$ \\
\hline Shushkashipaka ${ }^{13}$ & $\begin{array}{c}\text { Jeevaniya Ghrita, Anu } \\
\text { Taila }\end{array}$ \\
\hline Pakshmakopa $^{14}$ & Abhishyandokta Nasya \\
\hline Pitta Vidagdha Drishti ${ }^{15}$ & $\begin{array}{c}\text { Triphala Sarpi, Tilvaka } \\
\text { Sarpi }\end{array}$ \\
\hline Kapha Vidagdha Drishti15 & $\begin{array}{l}\text { Trivrut Sarpi, Tilvaka } \\
\text { Sarpi }\end{array}$ \\
\hline $\begin{array}{c}\text { Sashophaja Akshipaka \& } \\
\text { Ashophaja Akshipaka }{ }^{16}\end{array}$ & $\begin{array}{c}\text { Raktabhishyandavat } \\
\text { (Vairechanika Dravya + } \\
\text { Sita + Sarpi) }\end{array}$ \\
\hline Shleshmaja Timira ${ }^{17}$ & Goshakrut kwatha Taila \\
\hline Pittaja Timira ${ }^{17}$ & $\begin{array}{l}\text { Kevala Ghrita, Kakolyadi } \\
\text { Ghrita, Aja avika Ghrita }\end{array}$ \\
\hline Vata Raktaja Timira ${ }^{18}$ & $\begin{array}{l}\text { Sthiradi Taila, } \\
\text { Vidarigandha Taila, } \\
\text { Kakolyadi gana sidha } \\
\text { Taila, Anutaila }\end{array}$ \\
\hline Kevala Vataja Timira ${ }^{18}$ & $\begin{array}{c}\text { Sahashwagandhadi } \\
\text { Bala Shatavari Taila, } \\
\text { Trivrut Taila }\end{array}$ \\
\hline
\end{tabular}

Table 3.Various types of Nasya formulations indicated for different Netra Rogas by Acharya Vagbhata

\begin{tabular}{|c|c|}
\hline Disease & Drugs for Nasya \\
\hline Krichonmeelana ${ }^{19}$ & $\begin{array}{c}\text { Purana Sarpi+ Draksha+ } \\
\text { Sharkara }\end{array}$ \\
\hline Kumbhika vartma ${ }^{20}$ & $\begin{array}{c}\text { Nasya on } 4^{\text {th }} \text { day after } \\
\text { Lekhana }\end{array}$ \\
\hline Pakshma shatana ${ }^{21}$ & $\begin{array}{l}\text { Drakshadi sidha Ghrita } \\
\text { Nasya }\end{array}$ \\
\hline $\begin{array}{l}\text { Kaphotklishta } \\
\text { vartma }^{22}\end{array}$ & $\begin{array}{c}\text { Nasya with Kaphahara } \\
\text { Dravya }\end{array}$ \\
\hline Pakshmarodha ${ }^{23}$ & Teekshna Nasya \\
\hline Nimna Shukra 24 & Nasya \\
\hline Ajakajata $^{25}$ & $\begin{array}{c}\text { Ksheera Sarpi Nasya after } \\
\text { Vyadhana }\end{array}$ \\
\hline
\end{tabular}




\section{Result and Discussion}

Nasya Karma plays a very important role in Netra Rogas. At the same time, understanding the stage of eye disorder plays a pivotal role in deciding the administration of Nasya and its specificity. There are no direct contra-indications related with Netra Roga for Nasya. So considering certain conditions like diabetic retinopathy, hypertensive retinopathy, central serous retinopathy, etc., Nasya can be avoided when there is retinal vascular bleeding. Nasya if administered during these conditions may lead to more pressure towards these blood vessels which results in further bleeding. Shamana Nasya could be a better option for these conditions since it gives Dosha Shamana.

A Vaidya should be cautious while treating Netra Rogas. If the Nasya Karma is not done properly it will lead to Netra Vikaras. Atiyoga leads to Akshi Toda, Timira ${ }^{26}$ and Indriya Vibhrama ${ }^{27}$ which includes Netra Vibhrama. Ayoga leads to Indriya Rookshata which includes Netra Rookshata due to Vata Vaigunya ${ }^{27}$ and Akshi Stabdhata. ${ }^{28}$ Shodhana Karmas are supposed to do only after removing Ama Lakshana. Being Nasya, a Shodhana Karma, Netra should be free from Amavastha before administering Nasya. Or else because of the Srotavarodha the medicines will not get absorbed to the target, and may lead to other Netra Vikaras. That could be the reason why Acharya Charaka has told not to do Nasya Karma during Jwara and Shoka since it leads to Timira. ${ }^{29}$

Virechana Nasya can be done in conditions like Srotavarodha and when the Doshas are vitiated excessively. Dhmana Nasya and Avapidaka Nasya can be selected with Teekshna Gunayukta Dravyas like Gudardraka Nasya. It can be done when the Shamana Nasya is insufficient for Roga Shanti.

Brimhana Nasya can be done in conditions like Vata pradhana Netra Rogas and in congenital anomalies.

Pratimarsha Nasya can be done for almost all the diseases after considering the age of the patient and the time for Roga Shamana. It can be performed daily without the supervision of a Vaidya.

Along with selecting the type of Nasya according to the condition, time of administration of Nasya also has important role. It varies for different Doshaja Vyadhis.

It can be explained on the basis of Doshavastha in different Kala. Nasya is given in Pratah (morning) for Kaphaja Vikaras as Kaphadhikya is seen in Pratah. Madhyahna (mid noon) for Pittaja Vikaras due to Pittadhikya in Madhyahna and Sayahna (evening) and Nisha (night) for Vataja Vikaras due to Vatadhikya. In Sharat and Vasanta Ritu, it is given in Poorvahna (morning) due to Kaphadhikya. In Shita Ritus like Hemanta and Shishira it should be given in Madhyahna (mid noon) due to Pitta Shamana and Kapha Chhaya respectively. In Grishma Ritu, in Sayahna (evening) due to Vata Chhaya and Kapha Prashamana and Vatadhikya. In Varsha Ritu when there is presence of sun due to Pitta Chhaya and Vata Prakopa.

\section{Few Medicines which can be used for Nasya}

Pratimarsha Nasya: Anu Taila, Jeevantyadi Taila, Purana Ghrita

Marsha Nasya: Shadbindu Taila, Triphaladi Ghrita, Tungadrumadi Taila

Drishtiprasadanartha: Goshakrutadi Taila, Purana Ghrita

Nasya (Shirovirechana) is also a prerequisite to Rasayana Chikitsa. ${ }^{30}$ In some degenerative eye diseases like Cataract, refractive errors, ARMD, Retinopathy etc, Nasya is to be performed in order to eliminate vitiated Doshas and thereby achieve better absorption of Rasayana Dravyas.

Various previous studies also show the benefits of Nasya Karma in Netra Rogas. Role of Abhijit Taila Nasya and Murchita Tila Taila Nasya in Simple Myopia (Prathama Patalagata Timira) is already proved in which Abhijit Taila Nasya provided statistically better effect than Murchita Tila Taila Nasya in all the signs and symptoms. ${ }^{31}$

Another case study shows the benefit of Anu Taila Nasya in Shushkakshipaka (Dry Eye Syndrome) in which 7 days of Marsha Nasya showed marked relief in the symptoms of Shushkakshipaka. ${ }^{32}$

\section{Mode of Action of Nasya}

From the explanations given by different Acharyas about the mode of action of Nasya, certain assumptions can be made.

Nasa is the only passage to Shirah. So, the medicine taken through Nasa can easily move to Shirah and get absorbed.

Nasa being the passage to Shirah, the drug taken through nostrils reaches Shringataka, a Siramarma through Nasa Srota and enters the Murdha (Brain), through Netra (Eyes), Shrotra (Ears), Kantha (Throat) and puts out the morbid Doshas from Urdhwajatru and throws them out from Uttamanga. ${ }^{33}$

Drugs, in the form of Nasya has probable mode of entry in circulation, hence it can play a vital role in the improvement of eye health. Of course, the position of the head during Nasya Karma also helps the medicines to enter easily to the pathway. ${ }^{34}$ Probable mode of entry to the circulation might be as follows.

- By general blood circulation, after it is absorbed through mucous membrane.

- Direct pooling into venous sinuses of brain via, inferior ophthalmic veins.

- Absorption directly into the cerebrospinal fluid. As this medicine is absorbed in ophthalmic vessels it has its nourishing role in extra ocular muscles and eye 
proper. Along with this antioxidant property have role in maintaining tissue built. ${ }^{34}$

\section{Conclusion}

- Shodhana Karmas are always very effective before any therapy. Nasya being one among them is the best for Urdhwajatru Vikaras which includes Netra Vikaras.

- Comparing with other Shodhana Karmas, Nasya is less expensive and less complicated therapy. Since Nasya can give a Sthanika Shodhana of Shirah and Netra being situated in Shirah, it can act faster in Netra and can be more effective.

- Proper administration of Nasya in the early stages of Netra Rogas can even avoid unwanted surgeries even.

- Thus it promises a faster and effective therapy for the prevention and cure of Netra Rogas which have been already proven through various researches.

- ऊर्ध्वजत्रुविकारेषु विशेषान्नस्यमिष्यते $\mathrm{I}^{1}$ as righty quoted by Acharya Vagbhata.

\section{Scope for Further Study}

Even though various studies have undergone on Nasya Karma, options for further studies are still open. Few of them are:

- Clinical study on critical analysis and role of Poorva Karma and Pashchat Karma in Nasya.

- Literary work on different types of Nasya Karma and their specific mode of action.

\section{Conflicts of Interest: None References}

1. Sreekumar T. Ashtangahrdaya: Vagbhata sutrasthana: English translation \& commentary Publication Department, Harisree Hospital - 2011.P.107.

2. Radhakantadeva R. Shabdakalpadruma $2^{\text {nd }}$ Part; Edited by Shivaradaprasadvasuna and Sriharicharanavasuna. P.865.

3. Sushrutha, Ācārya Nārāyaṇa Rāma, Dalhaṇa Gayadāsācārya. Suśrutasaṃhitā. Ācārya Yādavaśarmā Trivikrama, editor. Vārāṇasī: Krṣnạāsa Akādamī; (2008); 55.

4. Vagbhata, Arunadatta, Hemadri. Ashtangahrdaya of Vagbhata, with the commentaries of Sarvangasundara and Ayurveda Rasayanam. Varanasi, U.P: Chaukhambha Surbharathi Prakashan; 2002. Annotation : Dr. Anna Moreshwar Kunte and Krishna Ramachandra Shastri Navre.P.290.

5. Sushrutha, Ācārya Nārāyaṇa Rāma, Dalhaṇa, Gayadāsācārya. Suśrutasaṃhitā. Ācārya Yādavaśarmā Trivikrama, editor. Vārāṇasī: Krṣnạāāsa Akādamī; (2008); P.633.

6. Sushrutha, Ācārya Nārāyaṇa Rāma., Dalhaṇa, Gayadāsācārya. Suśrutasaṃhitā. Ācārya Yādavaśarmā
Trivikrama, editor. Vārāṇasī: Krșṇadāsa Akādamī; (2008); 636.

7. Sreekumar T. Ashtangahrdaya: Vagbhata sutrasthana: English translation \& commentary Publication Department, Harisree Hospital - 2011; 108.

8. Sharma RK, Dash B. Charaka Samhita-English translation Vol. 1-6. Chowkhamba Sanskrit Series. 2000.P.356.

9. Sushrutha, Ācārya Nārāyaṇa Rāma., Dalhaṇa, Gayadāsācārya. Suśrutasaṃhitā. Ācārya Yādavaśarmā Trivikrama, editor. Vārāṇasī: Krșṇadāsa Akādamī; (2010); P.611.

10. Sushrutha, Ācārya Nārāyaṇa Rāma., Ḍalhaṇa, Gayadāsācārya. Suśrutasaṃhitā. Ācārya Yādavaśarmā Trivikrama, editor. Vārāṇasī: Krṣnadāsa Akādamī; (2010); 613.

11. Sushrutha, Ācārya Nārāyaṇa Rāma., Ḍalhaṇa, Gayadāsācārya. Suśrutasaṃhitā. Ācārya Yādavaśarmā Trivikrama, editor. Vārāṇasī: Krṣnạāāsa Akādamī; (2010); P.615.

12. Sushrutha, Ācārya Nārāyaṇa Rāma., Dalhaṇa, Gayadāsācārya. Suśrutasaṃhitā. Ācārya Yādavaśarmā Trivikrama, editor. Vārāṇasī: Krșṇadāsa Akādamī; (2010); 616.

13. Sushrutha, Ācārya Nārāyaṇa Rāma., Dalhaṇa, Gayadāsācārya. Suśrutasaṃhitā. Ācārya Yādavaśarmā Trivikrama, editor. Vārāṇasī: Krṣṇadāsa Akādamī; (2010); 612.

14. Sushrutha, Ācārya Nārāyaṇa Rāma., Ḍalhaṇa, Gayadāsācārya. Suśrutasaṃhitā. Ācārya Yādavaśarmā Trivikrama, editor. Vārāṇasī: Krṣnạāāsa Akādamī; (2010); 615.

15. Sushrutha, Ācārya Nārāyaṇa Rāma., Dalhaṇa, Gayadāsācārya. Suśrutasaṃhitā. Ācārya Yādavaśarmā Trivikrama, editor. Vārāṇasī: Krșṇadāsa Akādamī; (2010); 625.

16. Sushrutha, Ācārya Nārāyaṇa Rāma., Dalhaṇa, Gayadāsācārya. Suśrutasaṃhitā. Ācārya Yādavaśarmā Trivikrama, editor. Vārāṇasī: Krṣṇadāsa Akādamī; (2010); 618.

17. Sushrutha, Ācārya Nārāyaṇa Rāma., Ḍalhaṇa, Gayadāsācārya. Suśrutasaṃhitā. Ācārya Yādavaśarmā Trivikrama, editor. Vārāṇasī: Krṣnadāsa Akādamī; (2010); 627.

18. Sushrutha, Ācārya Nārāyaṇa Rāma., Dalhaṇa, Gayadāsācārya. Suśrutasaṃhitā. Ācārya Yādavaśarmā Trivikrama, editor. Vārāṇasī: Krṣṇadāsa Akādamī; (2010); 628.

19. Vagbhata, Ashtanga Hridaya. Nirmala-Hindi commentary by Bramanand Tripathi. Chaukhamba Sanskrit Pratishthan, Delhi. 2017. 940.

20. Vagbhata, Ashtanga Hridaya. Nirmala-Hindi commentary by Bramanand Tripathi. Chaukhamba Sanskrit Pratishthan, Delhi.2017. 940. 
21. Vagbhata, Ashtanga Hridaya. Nirmala-Hindi commentary by Bramanand Tripathi. Chaukhamba Sanskrit Pratishthan, Delhi.2017. 942.

22. Vagbhata, Ashtanga Hridaya. Nirmala-Hindi commentary by Bramanand Tripathi. Chaukhamba Sanskrit Pratishthan, Delhi.2017. 943.

23. Vagbhata, Ashtanga Hridaya. Nirmala-Hindi commentary by Bramanand Tripathi. Chaukhamba Sanskrit Pratishthan, Delhi. 2017. 945.

24. Vagbhata, Ashtanga Hridaya. Nirmala-Hindi commentary by Bramanand Tripathi. Chaukhamba Sanskrit Pratishthan, Delhi. 2017. 956.

25. Vagbhata, Ashtanga Hridaya. Nirmala-Hindi commentary by Bramanand Tripathi. Chaukhamba Sanskrit Pratishthan, Delhi.2017. 958.

26. Sharma RK, Dash B. Charaka Samhita-English translation Vol. 1-6. Chowkhamba Sanskrit Series. 2000. 170.

27. Sushrutha, Ācārya Nārāyaṇa Rāma., Dalhaṇa, Gayadāsācārya. Suśrutasaṃhitā. Ācārya Yādavaśarmā Trivikrama, editor. Vārāṇasī: Krṣnadāsa Akādamī; (2010); 556.

28. Vagbhata, Arunadatta, Hemadri. Ashtangahrdaya of Vagbhata, with the commentaries of Sarvangasundara and Ayurveda Rasayanam. Varanasi, U.P: Chaukhambha Surbharathi Prakashan; 2002. Annotation : Dr. Anna Moreshwar Kunte and Krishna Ramachandra Shastri Navre. 292.

29. Sharma RK, Dash B. Charaka Samhita-English translation Vol. 1-6. Chowkhamba Sanskrit Series. 2000.P.363.

30. Sharma RK, Dash B. Charaka Samhita-English translation Vol. 1-6. Chowkhamba Sanskrit Series. 2000.P.12.

31. Stuvert D. Role Of Abhijita Taila Nasya In The Management Of Prathama Patalagata Timira (Simple Myopia) (Doctoral dissertation).P.149.

32. Trunali D. Thakare, Kalpana S. Wakode.Role of Anu Taila Nasya in Shushkakshipaka (Dry eye syndrome)- A case study. World Journal of Pharmaceutical and Ayurvedic Sciences 2017; (5): 192.

33. Srikanthamurthy KR. Aștānnga samgraha of Vāgbhața: text, English translation, notes, indeces [sic] etc. Chaukhambha Orientalia; 2003; 511.

34. Solapurkar Vivek Vishwas \& S M Pasha: Madhukadi Taila Nasya In The Management Of Prathama Patalagata Timira - A Pilot Study. International Ayurvedic Medical Journal, 2018 Available from: http://www.iamj.in/posts/ images/upload/1925_1930.pdf. 